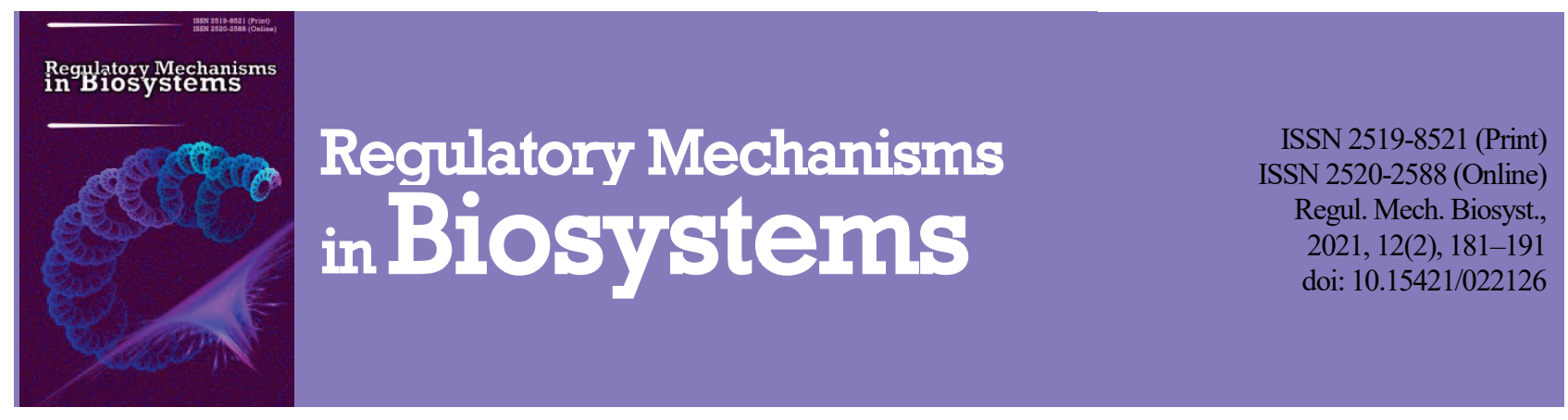

\title{
Neurophysiological mechanisms and features of autonomic support of productive cognitive activity of intuitive type in young adults
}

\author{
T. O. Tretyak*, I. M. Kofan*, O. M. Znanetska*, F. F. Boyechko**, O. V. Severynovska* \\ * Oles Honchar Dnipro National University, Dnipro, Ukraine \\ **Bohdan Khmelnytsky Cherkasy National University, Cherkasy, Ukraine
}

Article info

Received 26.04.2021

Received in revised form 21.05.2021

Accepted 22.05.2021

Oles Honchar Dnipro National University

Gaharin av., 72,

Dnipro, 49010, Ukraine.

Tel.: + 38-067-979-39-98.

E-mail:

irinakofan17@gmail.com

Bohdan Khmelnytsky

Cherkasy National University, Shevchenko Boulevard, 81 ,

Cherkasy, 18031, Ukraine.

Tel.: +38-0472-37-21-42.

E-mail: cic@cdu.edu.ua

Introduction

Human intellectual activity is multifaceted and belongs to the traditional targets of research in psychology. However, the works that combine a psychological approach with a neurophysiological one (Bekhtereva et al., 1985; Livanov et al., 1988) are of high value. A comprehensive psychophysiological approach allows us to approach the understanding of the basic mechanisms of various cognitive processes, to describe the patterns of their formation in ontogenesis, to investigate the causes of cognitive disorders, to develop methods for correcting the latter. The methods of electroencephalography and electrocardiography are the most frequently used to assess the physiological support of human intellectual activity (Craik et al., 2019). Traditionally, power indicators, as a characteristic of local activity of neural ensembles and coherence, as coordination of neural ensembles of different parts of the cerebral cortex, reflect various aspects of brain activity and cognitive control of left-handed and right-handed people (Bondarenko et al., 2016; Okhrei et al., 2016; Poruchynska et al., 2016).

Numerous basic studies indicate the relationship of various rhythmic and spatio-temporal parameters of the electroencephalogram with components of intellectual activity, such as visual (Yin \& Zhang, 2017; Fink et al., 2018; Talukdar et al., 2018), logical (Snezhkova et al., 2011; Kupa \& Filimonova, 2014) and intuitive (Vajz, 1998; Geraimchuk, 2012; Wan
SSN 2520-2588 (Online)

Regul. Mech. Biosyst.,

2021, 12(2), 181-191

doi: $10.15421 / 022126$

tion which is based on the disclosure of . For the first time with the use of cerebral cortex electrical activity mapping, a comprehensive study of the organization of cortical of the electroencephalogram. The synchronization of the activity of most frequency bands is manifested in the frontal and motor areas of

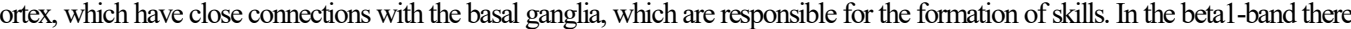
and theta-bands of the electroencephalogram they are combined into large cellular ensembles that cover the central-parietaltemporal loci of the cortex. Synchronization of biopotentials in the delta range covers large areas of the cerebral cortex. It has been estab-

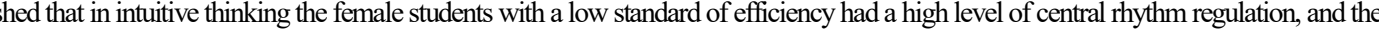
female students with a high standard of efficiency had a high level of autonomous regulation. Higher performance under intuitive thinking mean squares of the intervals between heartbeats (rMSSD) in the structure of cardiorhythm Correlation analysis found that productive me specific integration of cortico-visceral processes: productive intuitive thinking is associated with the activation of autonomic regulation of heart rate variability and coherence in the evolutionarily older delta and delta-theta systems of the cerebral cortex can serve as objective criteria for successful intuitive thinking, which allow one to predict both individual abilities and the

Keywords: mental activity; intuitive thinking; information processing; electroencephalogram; spectral power; coherence; cardiointervalography; autonomic nervous system; female students; regulatory mechanisms.

et al., 2012) thinking. There are also a number of studies in which the researchers link certain EEG parameters with the success of cognitive activity (Karpova \& Dikaya, 2014; Sastre-Riba \& Ortiz, 2018). Some researchers point to the dependence of the effectiveness of perception and processing of information on the phase of the menstrual cycle in women (Makarchuk et al., 2010). It should be noted that successful performance is one of the important factors influencing the state of psychological and emotional comfort during the education process, which in turn ensures the adequate performance of professional duties and minimizes the negative impact on human health. This determines the relevance of the study of physiological support of intellectual activity in order to identify physiological factors that contribute to achieving high results.

The problem of development of thinking both as a whole and in terms of its individual types, the study of the pedagogical conditions of its formation, has become especially relevant in the context of an innovative approach to learning that places high demands on the formation of new competencies and students' ability to use productive ways of thinking, reflective analysis (Konogorskaya, 2017). Many studies recognize the relationship and interdependence of personal and cognitive components of academic performance, which increases the importance of their study both individually and in combination (Tikhomirova et al., 2015; Samokhin et al., 2016). The state of evident stress of regulatory systems leads to a 
violation of the autonomic balance and reduced adaptive capacity of the body, which affects not only the successful learning, but also the health of students. Therefore, the in-depth study of the full range of objective indicators that could be used to monitor, predict and, if necessary, adjust the functional state of the human body is relevant and well-timed. To assess and predict the functional state of intellectual activity a fairly informative method of analysis of heart rate variability is used (HRV) (Baevskij et al., 2001; Riganello et al., 2010; Kucenko et al., 2013; Lyzohub et al., 2014).

In general, despite the large amount of experimental material, the results of human EEG research during the performance of various intellectual tasks are contradictory and do not allow us to unambiguously correlate the parameters of biopotentials with specific psychophysiological processes. The researchers often do not take into account that the performance of an intellectual task by persons with different background indicators of the global spatial organization of the potentials of the cortex depends on their personal characteristics and skills, and that women of reproductive age are dependent on hormonal background.

The problem of finding universal electrophysiological indicators that would be reliably related to successful performance of intellectual tasks for different types of thinking still remains unresolved. Far from being solved is also the question of topographic patterns of activation and inhibition processes, which form the physiological basis of intellectual actions of people and ensure the effectiveness of cognitive activity.

Although intuitive thinking is the least understandable of all human cognitive activities, it is one of the most widely used and powerful ways of cognition. Most of the decisions we make in life are based on our intuitive feelings (responses), but the neurophysiological mechanisms of this decision-making process are still the least studied. At the level of experience, intuition does not withstand the logical ways of cognition. The authors (Voss \& Paller, 2009) proved that one of the characteristics of memory is that the retrieval of information from memory can occur in unawareness and is perceived by a person as guessing (intuitive response). Therefore, the scientists believe that intuition is based on automatic processes that are based on the knowledge acquired in the result of learning. In gener$\mathrm{al}$, intuition is an unconscious process that influences the behaviour based on implicit knowledge, in which information is actively processed in the cerebral cortex. Intuition can be understood as the process of attaching implicit memories to the conscious and subconscious memory systems.

The study published Voss \& Paller (2009) shows that the search for explicit and implicit memories involves different neural substrates and mechanisms. In fact, the studies show that encoded and stored stimuli were memorized better when the subject was distracted compared with the stimuli that are directly encoded by the will. These studies indicate that intuition is more likely to be a product of learning than a mystical innate "sixth sense".

There is still no single point of view on what particular characteristics of HRV are the most adequate correlates of successful intuitive activity. We suggest that the lability of physiological functions, which is manifested at the peripheral (vegetative indicators) and central (under EEG parameters) levels may contribute to the productivity of the above mentioned type of mental activity. The development and implementation of new teaching methods involve the transition from a low level of activity to a higher one, which is based on neurovegetative mechanisms of thinking processes, the study of the latter determines the relevance of the chosen topic.

The purpose of the study is to elucidate the neurophysiological mechanisms and features of the autonomic support of productive cognitive activity of female biology students engaged in intuitive type of thinking.

\section{Materials and methods}

The research plan was agreed and approved by the Bioethics Commission of Oles Honchar Dnipro National University. All the researches were conducted in accordance with the principles of bioethical norms of World Medical Association Declaration of Helsinki on Ethical Principles for medical research Involving Human Subjects (1964-2000), Universal Declaration on Bioethics and Human Rights (UN, 1997), Convention on for the Protection of Human Rights and Dignity with regard to the Appli- cation of Biology and Medicine (Oviedo, Spain, 1997), Declaration of Tolerance Principles (1995), the Order of the Ministry of Health of Ukraine dated Feb.13, 2006 No. 66.

175 female students aged 18-22 of the Faculty of Biology and Ecology, Oles Honchar Dnipro National University, passed the preliminary survey. The main study involved the female students aged 20-22 years $(n=93)$, right-handed people with a regular menstrual cycle lasting 2633 days, who were not taking hormonal contraceptives. All the participants were healthy, were not taking medication at the time of the study, did not have neurological or psychiatric illnesses, and did not complain of fatigue or drowsiness. Each participant participated in the study during the follicular phase (4-7 days). The research was conducted in the office of functional diagnostics. According to the results of psychophysiological testing for intuitive thinking, the subjects were divided into groups with low and high productivity of the given type of thinking.

The students performed the test tasks during 5 minutes. After each test there was a 15-minute-break. The state of health of the subjects was recorded. At the end of the study, the performance of the task was determined as a percentage. Photographs of plants, animals, fungi, and human muscles and bones with the figure captions in Latin were used in the study of intuitive thinking. The students had to choose intuitively the correct answer from the suggested ones. All the objects were selected from the program material for self-study from the disciplines of the general block, which were taught in the first year of study.

Using the complex for registration and processing of EEG and the evoked potentials DX-NT32.V19 (Kharkiv, Ukraine) in the process of mental activity the multi-channel registration of EEG activity according to the scheme $10-20$ with a signal quantization frequency of $250 \mathrm{~Hz}$ on each channel was carried out and SP and coherence were determined. The EEG was taken from the symmetrical pairs of the following leads: Fp1, Fp2, F3, F4, C3, C4, P3, P4, O1, O2, F7, F8, T3, T4, T5, T6. The combined electrodes fixed on the earlobes were the referent. The neutral electrode was located on the forehead. Each student participated in the research twice: in a preliminary examination for the absence of pathology, and in the experiment itself. Five-minute EEG intervals were recorded. During the Fourier implementation, the analysis epoch was $500 \mathrm{~ms}$. The sampling frequency of the analog signal was $2 \mathrm{~ms}$; input resistance for inphase signal was more than $100 \mathrm{MOhm}$. High-pass filters were installed at $50 \mathrm{~Hz}$, low ones - at $0.5 \mathrm{~Hz}$. The limits of possible relative error when measuring voltage and time intervals of EEG signals were $\pm 5 \%$. The removal of EEG artifacts was performed by an expert method in the mode of viewing the record, according to the program of the device. The minute record was analyzed, for which the average values of normalized SP and coherence for symmetrical hemispherical and interhemispheric pairs of leads in the frequency bands corresponding to delta- (1$4 \mathrm{~Hz})$, theta- $(4-8)$, alpha- $(8-13)$, betal- $(13-20)$ and beta2- $(20-30 \mathrm{~Hz})$ rhythms were calculated.

During the cognitive tests performance, 5-minute recordings of cardio intervals were recorded using a 12-channel electrocardiograph "Sphere-4" (RPC “Diagnostic Systems” Ltd., Nizhny Novgorod, Russia). The ECG processing was performed on the basis of the Sphere-4 software package, which performs HRV analysis in accordance with the recommendations of International Standard. Statistical and diagnostic indicators of cardiointervalography and spectral indicators of HRV were analyzed: the mean square deviation of all normal sinus R-R intervals (SDNN), the value of the length of the R-R interval, where mode is the most common (Mo, s), the number of R-R intervals, corresponding to the values of Mo, which is expressed as a percentage (AMo,\%), the coefficient of variation of the duration of $R-R$ intervals $-C V(\%)$, the variation range $(\Delta X, R V U)$, which is the difference between the maximum and minimum values of the duration of cardiocycles, the secondary integral indicator, which reflects the degree of centralization of heart rate control, that is stress index (SI, RVU), voltage index of regulatory systems (IN, RVU), which characterizes the degree of functional adaptive-compensatory mechanisms of the body, autonomic rhythm (VPR, RVU), the index of autonomic balance (IVR, RVU) which indicates the relationship between the activity of the sympathetic and parasympathetic divisions of the ANS, the adequacy of regulatory processes (ARP, RVU) which reflects the correspondence between the activity of the sympathetic ANS and the leading level of sinus 
node functioning, the activity of adrenergic or cholinergic mechanisms of the humoral regulation channel, the value of the square root of the mean squares of the intervals between heartbeats, number of pairs - rMSSD cardio intervals that differ by more than $50 \mathrm{~ms}-\mathrm{pNN} 50 \%$. The accurate quantitative assessment of periodic heart rate processes was performed using the spectral analysis, which allowed us to assess the activity of separate levels of heart rate control. The names of the spectral components according to European-American standards reflect the frequency composition of the total power spectrum (Total power - TP) of neurohumoral regulation: high frequency oscillations (High Frequency - HF), low frequency oscillations (Low Frequency - LF), "very" low frequency oscillations - VLF). Spectral analysis was used to calculate the following: absolute spectral power (HF, LF, VLF), average power in the range $(\mathrm{HF} \%$, LF\%, VLF\%); centralization index (IC, RVU) and heart rate frequency (HRF) were registered.

Statistical analysis of the data was performed using the package Statistica 6.0 (StatSoft Inc., USA, 2001). Since the distribution of the vast majority of indicators was different from normal one (according to the Lilliefors test), the Wilcoxon T-test was used to compare the dependent samples, and the Mann-Whitney U-test was used to compare the independent samples. The critical level of significance in testing of statistical hypotheses was taken as equal to $\mathrm{P}<0.05$. The medians of both the lower and upper quartiles $(\mathrm{Me}[25 ; 75])$ were indicated to describe the sample distribution. The empirical correlation coefficient was calculated, and the correlation with the level of $\mathrm{P}<0.05$ was considered reliable.

\section{Results}

The transition from rest (closed eyes) to cognitive activity was accompanied by depression of the alpha- and the dominance of beta1rhythm (Table 1). At the same time, the indicators of theta components of EEG and asymmetry strengthening were high.

In the process of intuitive problem solving in both groups there was a decrease in absolute SP of alpha oscillations, but with increasing productivity of tests performance it was more pronounced: inhibition of SP of alpha components of EEG covered all the parts of the cerebral cortex of both hemispheres, which is characteristic of mental activity. The results of comparing the values of the spectral power of the EEG showed that with increase in the effectiveness of intuitive thinking SP in the alpha range decreased in the parietal, occipital and temporal loci of both hemispheres and in the central zone of the left and anterior F8 zone of the right hemisphere, and in the betal band there were lower values in the central, parietal and occipital loci of both hemispheres of the brain (Fig. 1). In contrast to betal activity associated with alpha rhythm, beta2 components of the EEG are relatively independent, and their power in intuitive thinking increased in individuals of both groups, especially in high-productive ones. The results of comparing the values of SP delta and theta oscillations in the students with different productivity of intuitive thinking indicate a probable increase in power in the above ranges of EEG in the anterior areas of the cortex in individuals with higher productivity of intuition task performance.

\section{Table 1}

The relative power of the rhythmic components of the EEG in female biology students with different productivity of intuitive thinking (\%)

\begin{tabular}{|c|c|c|c|c|c|c|c|c|}
\hline \multirow{3}{*}{$\begin{array}{l}\text { Relative power } \\
\text { of EEG components }\end{array}$} & \multicolumn{4}{|c|}{$\begin{array}{c}\text { Indicators of female students with low productivity } \\
\text { of intuitive thinking, } n=47\end{array}$} & \multicolumn{4}{|c|}{$\begin{array}{l}\text { Indicators of female students with high productivity } \\
\text { of intuitive thinking, } n=46\end{array}$} \\
\hline & \multicolumn{2}{|c|}{ background values (eyes closed) } & \multicolumn{2}{|c|}{ during intuitive thinking } & \multicolumn{2}{|c|}{ background values (eyes closed) } & \multicolumn{2}{|c|}{ during intuitive thinking } \\
\hline & $\mathrm{Me}$ & $\mathrm{Q}_{25}-\mathrm{Q}_{75}$ & $\mathrm{Me}$ & $\mathrm{Q}_{25}-\mathrm{Q}_{75}$ & $\mathrm{Me}$ & $\mathrm{Q}_{25}-\mathrm{Q}_{75}$ & $\mathrm{Me}, \%$ & $\mathrm{Q}_{25}-\mathrm{Q}_{75}$ \\
\hline Delta activity & 3.8 & $3.3-4.1$ & $9.3^{* *}$ & $8.8-9.9$ & 3.5 & $3.1-4.0$ & $10.3^{* *}$ & $9.2-11.8$ \\
\hline Theta activity & 21.3 & $19.1-25.2$ & 24.6 & $23.5-25.0$ & 19.3 & $17.0-24.3$ & $26.4^{* * *}$ & $25.6-27.4$ \\
\hline Alpha rhythm & 50.3 & $44.8-56.3$ & $10.2^{* * * *}$ & $9.3-10.7$ & 53.5 & $47.0-56.4$ & $2.4^{* \ldots \#}$ & $2.0-2.9$ \\
\hline Betal activity & 24.2 & $20.3-28.7$ & $40.4^{* *}$ & $38.4-42.5$ & 22.6 & $19.6-37.8$ & $49.7^{* * \# \#}$ & $48.6-51.5$ \\
\hline Beta2 activity & 0.5 & $0.1-1.4$ & $15.5^{* * *}$ & $13.9-15.1$ & 1.2 & $0.8-1.9$ & $11.2^{* * * * \#}$ & $10.2-12.4$ \\
\hline $\begin{array}{l}\text { The value of the indicator } \\
\text { of interhemispheric asymmetry }\end{array}$ & 6.6 & $5.7-7.2$ & $9.2^{* *}$ & $8.4-10.4$ & 8.9 & $7.9-9.2$ & $11.3^{* * \#+1}$ & $10.5-12.4$ \\
\hline
\end{tabular}

Notes: probably relative to background values, at $* \mathrm{P}<0.05,{ }^{* *} \mathrm{P}<0.01,{ }^{* * *} \mathrm{P}<0.001$; relative to the indicators of female students with low performance, at ${ }^{\#} \mathrm{P}<0.05$, ${ }^{*} \mathrm{P}<$ 0.01 by Mann-Whitney $U$ test.
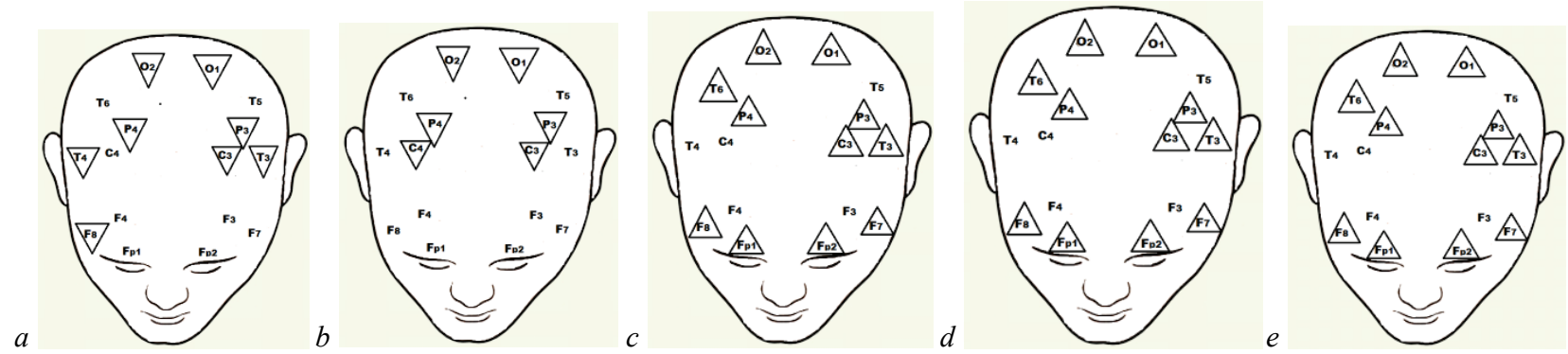

Fig. 1. EEG lead points at which probable changes in spectral power occur with increasing productivity of intuitive thinking: $a$-alpha- frequency range, $b$-beta1- frequency range, $c$ - beta2-frequency range, $d$ - delta-frequency range, $e$-theta-frequency range; the triangle with the top down-a decrease, and the triangle with the top up - an increase in spectral power of EEG components in the students with high productivity of intuitive thinking $(n=46)$ in comparison with the students with low productivity $(\mathrm{n}=47)$, at level of significance $\mathrm{P}<0.05$

Due to the use of methods of mathematical analysis of multichannel registration of electrical activity of the brain, computer topographic mapping of electrical activity of the brain became possible, which is used to analyze complex mental phenomena such as unconscious mental acts, including those related to parapsychology. Thus, in terms of size and number of coherent connections, we tried to assess the degree of functional connection based on the results of electrical processes recording on the surface of the cerebral cortex during irrational intuitive responses of the female biology students. In the students with low performance of intuitive thinking in the alpha range of the EEG significant coherent relationships of medium $(\mathrm{Cog}=0.62-0.64, \mathrm{P}<0.05)$ and high $(\mathrm{Cog}=0.74-0.86, \mathrm{P}<0.05)$ degree in the anterior parts of the left and posterior loci of the right hemispheres, symmetrical short and long connections between the two hemispheres were found. The high coherences in the central-parietal-temporal loci of both hemispheres and between them were especially noteworthy (Table 2). In the students with high productivity of intuitive thinking, in the alpha range of the EEG the number of significant coherent connections is increased: significant coherence $(\mathrm{Cog}=0.62-0.94, \mathrm{P}<0.05)$ in the anterior and posterior parts of both hemispheres, significant interhemispheric $(\mathrm{Cog}=0.63-0.76, \mathrm{P}<$ $0.05)$ connections in the anterior cortex, interhemispheric short ones between all symmetrical leads. However, the number of central-parietaltemporal coherences in the right hemisphere and between the two hemispheres is reduced, compared to low-productive individuals (Table 2). 
Table 2

Functional connections of the cerebral cortex in different ranges of EEG in female students with low productivity of intuitive thinking when performing tasks

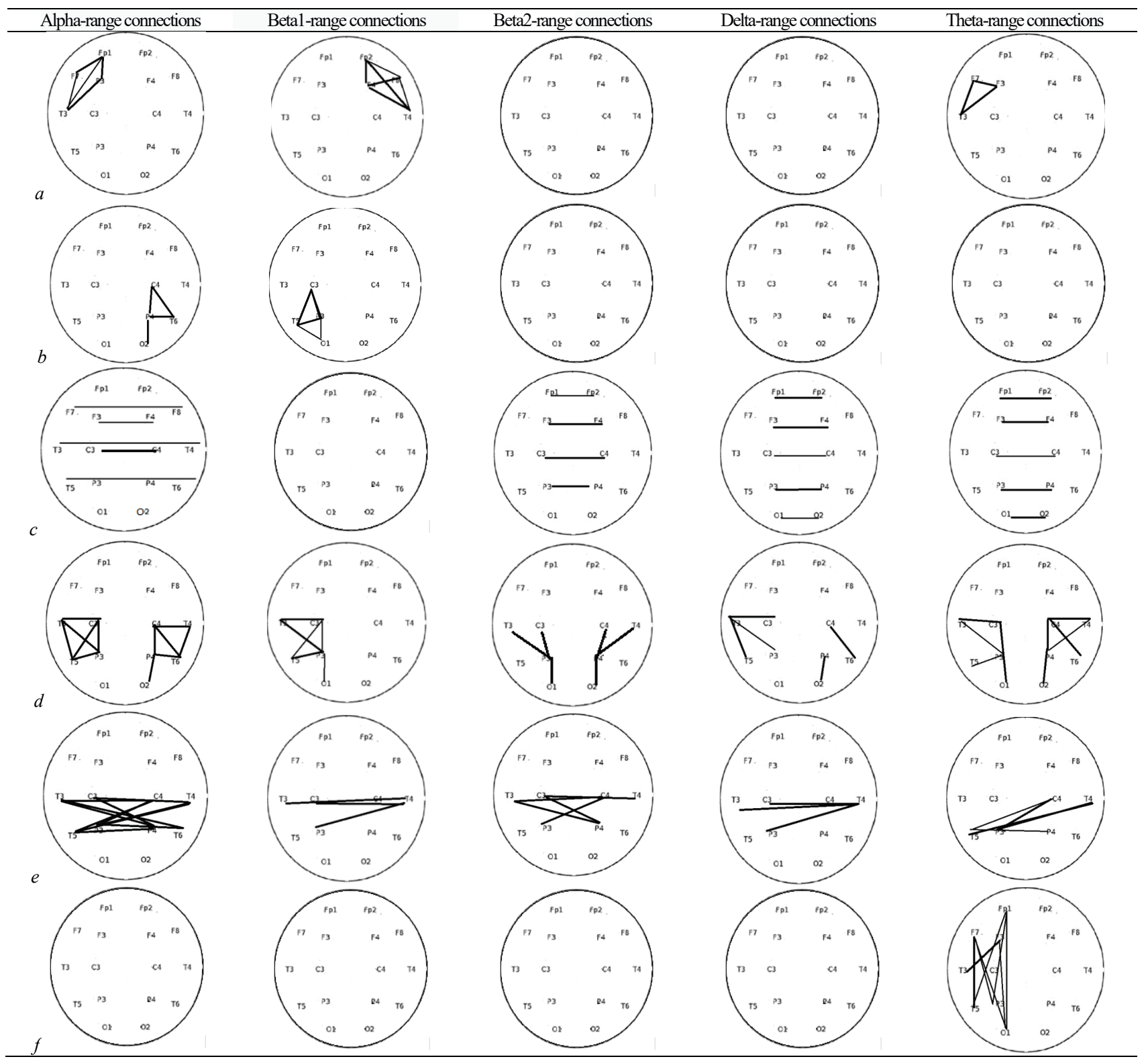

Notes: $\mathrm{n}=47$, thin line - coherent connections of medium degree $(\operatorname{Cog}=0.60-0.67, \mathrm{P}<0.05)$, thick line - coherent connections of high degree $(\mathrm{Cog}=0.70-0.96, \mathrm{P}<0.05)$; types of coherent connections: $a$ - connections in the anterior parts of the right and left hemispheres; $b$-connections in the posterior parts of the right and left hemispheres; $c$ short and long interhemispheric connections between symmetrical leads; $d$-central-parietal-temporal connections of the right and left hemispheres; $e$-interhemispheric centralparietal-temporal connections; $f$-intrahemispheric long connections between the anterior and posterior parts of the left hemisphere.

Table 3

Functional connections of the cerebral cortex in different ranges of EEG in female students with high productivity of intuitive thinking during task performance

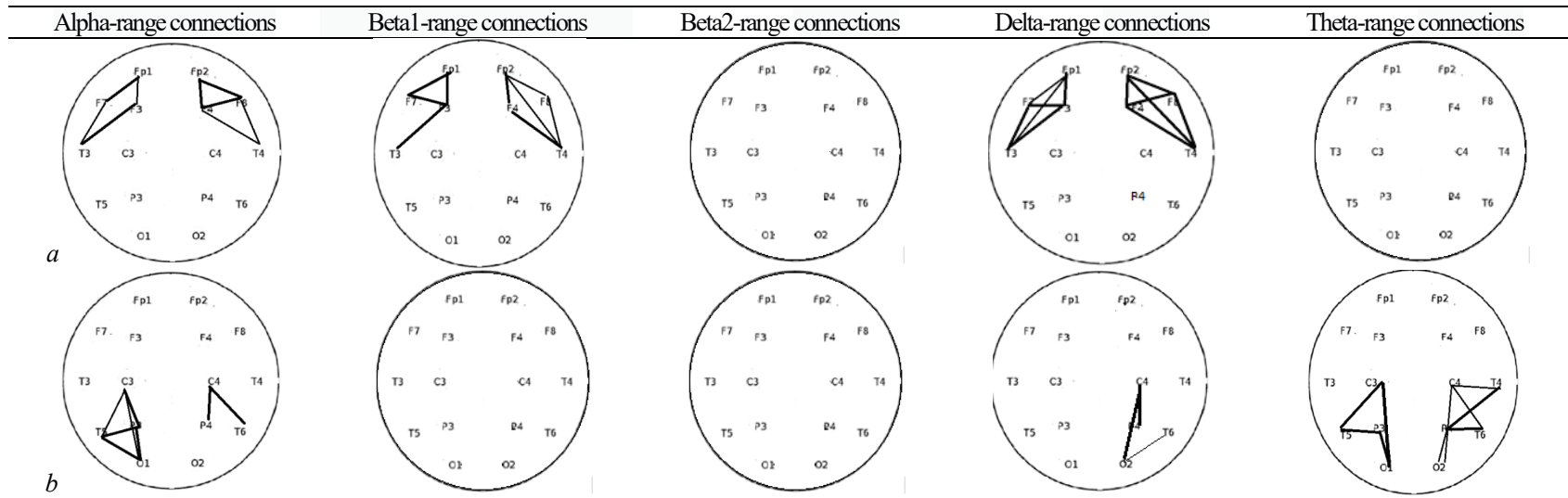




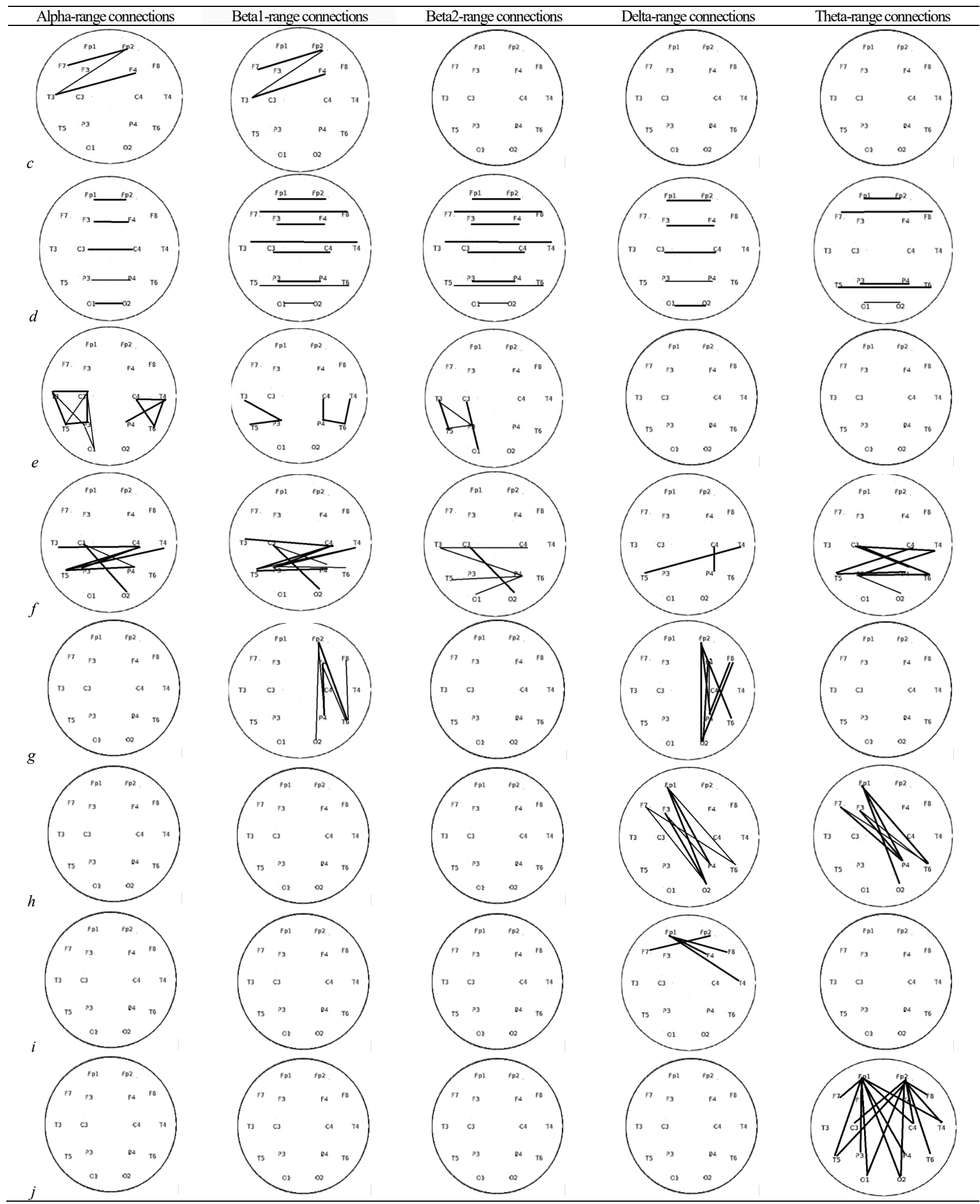

Notes: $\mathrm{n}=46$, thin line - coherent connections of medium degree $(\operatorname{Cog}=0.60-0.67, \mathrm{P}<0.05)$, thick line - coherent connections of high degree $(\operatorname{Cog}=0.70-0.95, \mathrm{P}<0.05)$; types of coherent connections: $a$ - connections in the anterior parts of the right and left hemispheres; $b$-in the posterior parts of the right and left hemispheres; $c$-interhemispheric connections in the anterior cortex; $d$ - short and long interhemispheric ones between symmetrical leads; $e$ - central-parietal-temporal connections of the right and left hemispheres; $f$ - interhemispheric central-parietal-temporal connections; $g$ - intrahemispheric long connections between the anterior and posterior parts of the right hemisphere; $h-$ interhemispheric diagonal connections between the anterior parts of the left hemisphere and the posterior parts of the right; $i$-interhemispheric connections in the anterior parts of the cortex; $j$ - between the frontal leads and other points of both hemispheres.

It should also be noted that in the alpha range when performing tasks on intuition in both groups probable connections in leads F3-F4, C3-C4, P3-P4, and in high-productive students - also high coherence in Fp1-Fp2 and $\mathrm{O} 1-\mathrm{O} 2$ pairs of leads were established. In the EEG of the female students with a low level of productivity of intuition tasks' performance, significant coherences in the betal-range in the anterior zone of the right and posterior areas of the left hemisphere were marked; central-parietaltemporal connections in the left hemisphere and interhemispheric centralparietal-temporal synchronizations were established (Table 2). In the students with high productivity of intuitive thinking, the number of proba- 
ble coherent connections in the above-mentioned EEG band is increased. Significant coherent connections were established $(\mathrm{Cog}=0.60-0.85, \mathrm{P}<$ 0.05 ) in the anterior parts of both hemispheres, probable interhemispheric synchronizations appear in the anterior parts of the cortex. Productive individuals also had short and long interhemispheric connections between symmetrical leads, and synchronization in the central parietal-temporal zone increases. The appearance of probable intrahemispheric long coherences between the anterior and posterior parts of the right hemisphere should be noted particularly (Table 3 ).

When performing tests, the synchronization of oscillations in the beta2-frequency range of the EEG between short symmetrical interhemispheric leads in the low-productive female students and between short and long symmetrical interhemispheric leads in the successful ones when performing intuition tasks took place (Table 2). Probable synchronizations in the central-parietal-temporal zones of both hemispheres in less productive female students were also established, which with increasing efficiency persist only in the left hemisphere (Table 3 ). Both groups are characterized by interhemispheric central-parietal-temporal relationships.

Having assessed the synchronicity of the brain during intuitive responses in the students with low scores, a probable level of interhemispheric coherence in the delta range between symmetrical leads of brain structures and in the central parietal-temporal areas of both hemispheres, and in the same loci between the two hemispheres of the cerebral cortex was established (Table 2). With the increase of productivity, there was an increase in the number of significant connections in the delta range. The obtained data indicate that in most cases the success of the activity was accompanied by the emergence of synchronization loci in the anterior parts of the left and right hemispheres and in the posterior regions of the right hemisphere. Also the interhemispheric diagonal Cogs between the anterior parts of the left hemisphere and the posterior parts of the right were significant and short interhemispheric connections between symmetrical leads (and central parietal-temporal ones) were preserved. At the same time, new synchronization centers were recorded (Table 3 ).

In the theta range in the low-performance female students, the synchronization of EEG oscillations was observed in the left hemisphere, covering the anterior-posterior and central-parietal-temporal divisions and in the central-posterior divisions of both hemispheres (Table 2). Signifi- cant coherences $(\mathrm{Cog}=0.60-0.84, \mathrm{P}<0.05)$ were recorded between the symmetrical leads of both hemispheres. In the female students with high productivity of intuitive thinking, increased intrahemispheric and interhemispheric synchronizations of theta-derived EEG were observed in the posterior cortex. There were significant $(\mathrm{Cog}=0.66-0.88, \mathrm{P}<0.05)$ interhemispheric connections between symmetrical leads and diagonal coherences between the anterior parts of the left cortex and posterior - right, short and long ones, and central-parietal-temporal-occipital synchronizations in both hemispheres, as well as significant synchronization between the frontal Fp1 and Fp2 leads and other points of the cortex (Table 3).

Thus, although the mechanisms of intuition are not fully known, it is clear that at the frequency of theta waves there is a significant difference in the spatial organization of electrical processes depending on the effectiveness of the task. Also noteworthy is the fact of high $(\mathrm{Cog}=$ $0.81-0.83, \mathrm{P}<0.05$ ) coherence coefficients in the leads of Fp1-Fp2 (Tables 2, 3). Thus, it can be stated that in people with higher productivity of performing intuitive thinking tasks more pronounced loci of increased activity (synchronization) of biopotentials are registered, especially in the frontal areas of the cortex, while in the less successful ones activation is diffuse or insignificant.

In various types of work, including training, the success of work depends largely on the functional state of the organism, so the next stage of the study was to assess the autonomic tone and activity of the regulation mechanisms, which was carried out by the method of heart rate variability (according to statistical analysis of the time series of cardio intervals) during the performance of tasks on intuitive thinking. Important criteria for rapid assessment of the predominant type of heart rate regulation (central or autonomous one) during physical or mental activity are the following indicators: SI (stress index), TSP (total spectrum power) and VLF (power "VERY" low-frequency components of the spectrum). In our study it was found that against the background of the tendency to decrease the spectral power of VLF in female biology students of both groups, divergent probable changes in SI and TSR were observed: decrease in TSR and increase in SI in the low-productive students, increase in TSR and decrease in SI in high-productive students, which suggested different types of regulation of the cardiovascular system in persons with different efficiency of task performance (Table 4).

Table 4

Determining type of regulation of heart rate during intuitive thinking based on the analysis of the assessment of the functional state of the body's regulatory systems

\begin{tabular}{|c|c|c|}
\hline \multirow{2}{*}{ Indicators } & \multicolumn{2}{|c|}{ Groups } \\
\hline & Low-productive & High-productive \\
\hline SI, y.o. & $>100$ & $<100$ \\
\hline VLF, $\mathrm{mc}^{2}$ & $>1000$ & $>1000$ \\
\hline Statistical parameters of $\mathrm{HRV}$ & $\begin{array}{l}\text { increase in heart rate, decrease in } \mathrm{R}-\mathrm{R} \text { interval } \\
\text { and } \mathrm{CV} \text { coefficient of variation }\end{array}$ & $\begin{array}{l}\text { decrease in heart rate, increase in } \mathrm{R}-\mathrm{R} \text { interval } \\
\text { and } \mathrm{CV} \text { coefficient of variation }\end{array}$ \\
\hline Humoral balance & does not change & increase of Mo \\
\hline $\begin{array}{l}\text { Diagnostic indicators of HRV: } \\
\text { - sympathetic department of the ANS } \\
\text { - parasympathetic department of the ANS }\end{array}$ & $\begin{array}{l}\text { increase of AMO, SI, IN, IVR } \\
\text { decrease of SDNN, pNN50 }\end{array}$ & $\begin{array}{c}\text { decrease of AMO, IN, SI, IVR } \\
\text { increase in } \Delta \mathrm{X}, \mathrm{SDNN}, \mathrm{rMSSD}, \mathrm{pNN} 50\end{array}$ \\
\hline Adequacy of regulatory processes & PAPR increase & PAPR decrease \\
\hline HRV spectral indices & $\begin{array}{c}\text { moderate decrease in absolute values of TP, predominance of } \\
\text { LF-waves over VLF and HF. An increase in the relative } \\
\text { amount of LF and a decrease in HF }\end{array}$ & $\begin{array}{c}\text { moderate increase in absolute values of TR, HF. } \\
\text { moderate predominance of the relative amount } \\
\text { of HF over LF waves }\end{array}$ \\
\hline Characteristic type of spectrum & $\mathrm{LF}>\mathrm{HF}>\mathrm{VLF}$ & $\mathrm{HF}>\mathrm{LF}>\mathrm{VLF}$ \\
\hline $\begin{array}{l}\text { Balance between activity of segmental and } \\
\text { suprasegmental contours of vegetative management }\end{array}$ & IC within the background values & IC within the background values \\
\hline Interpretation of the obtained data & $\begin{array}{l}\text { moderate predominance of sympathetic and central regulation } \\
\text { of heart rhythm, decrease in activity of autonomous contour of } \\
\text { regulation. moderate stress of the body's regulatory systems }\end{array}$ & $\begin{array}{l}\text { moderate predominance of parasympathetic activity the } \\
\text { optimal state of the body's regulatory systems displays the } \\
\text { normal level of response to exercise }\end{array}$ \\
\hline
\end{tabular}

The results of our study show that during mental load the autonomous regulation of the cardiovascular system occurs due to the coordinated work of many links. A systematic approach to the consideration of a complex mechanism of physiological functions' regulation, which can be judged from the analysis of HRV, allowed us to identify the features of these processes in the female students depending on the performance of intuition tasks. Low-productive female students showed not only lower performance, but also lower functional and adaptive capabilities of the body.
The reaction of HVS when performing intuitive thinking tasks was manifested in them in increasing heart rate and reduction in R-R-interval, reduction in the coefficient of variation (CV), Mo, rMSSD, pNN50, SDNN and increasing AMO, stress index, vegetative index IVR), PAPR. All this indicates a moderate stress on the body's regulatory systems. In highproductive individuals, the heart rate probably decreases, the R-R interval and its coefficient of variation increase, and Mo increases. Indicators of sympathetic and parasympathetic links of regulation indicate the predo- 
minance of the latter. Spectral indicators of HRV with intuitive ones indicate a moderate increase in the absolute values of TR, HF, LF. There is moderate predominance of $\mathrm{HF} \%$ over $\mathrm{LF} \%$ waves and the increase in the centralization index. The next step in our study was to identify the relationship between EEG scores and heart rate variability in intuitive thinking: a correlation analysis was performed to identify the relationship between mental performance and EEG characteristics and HRV scores in groups of students with different levels of intuition task performance. In the girls with low productivity of intuitive thinking, two interhemispheric significant positive relationships were found between performance and EEG coherence in the alpha range in the temporal-parietal area, two divergent correlations between performance and coherence in the frontal pole and occipital loci in the left hemisphere, and three different sign correlations between performance and coherence centered in the parietal abduction of the right hemisphere. With increasing productivity of intuitive thinking, a decrease in interhemispheric coherence in the betal range of EEG in pairs Fp2-T3 and P4-T5 was recorded, three left-hemispheric and two right hemispheric connections were recorded. Significant correlations between productivity and interhemispheric and right hemispheric coherence of different areas in the delta range and left hemisphere in the theta band of EEG with location in the lead Fpl were recorded.

In more productive students, the number of correlations between performance and coherence in the alpha range of the EEG was greater: seven interhemispheric (two of them negative ones) and three right- and lefthemispherical ones, mostly positive with the center in the frontal leads of both hemispheres. In addition, in these students the negative coherence between performance and absolute $\mathrm{SP}$ at points F3, O1, F8, P4 was recorded. Close negative relationships were found between performance and absolute spectral power in the central and parietal leads in the betal and F7 points in the beta 2 bands of the electroencephalogram. Between performance and coherence in beta 1, 2 ranges were registered: 8 interhemispheric, 1 left hemispheric, 3 right hemispheric and 5 interhemispheric, 2 left hemispheric and 3 right hemispheric connections, both positive and negative ones. High-productive female biology students were characterized by a significant number of positive correlations between performance and coherence in the low-frequency EEG ranges: in 4 interhemispheric and 6 right hemispheric and 7 interhemispheric (in the anterior cortex of both hemispheres), 2 left hemispheric and 3 right hemispheric respectively (in the anterior and central areas of both hemispheres).

The obtained correlation coefficients indicate the presence of a much larger number of close relationships (mostly positive ones) in high-productive female students, which to a greater extent coincide with certain coherences. It was also determined that in low-productive students (group II) the success of the intuition task was negatively correlated with the R-R interval of the CIG and with the over-low-frequency (VLF) component of the spectrogram and positively - with the low-frequency (LF) component of HRV. In group I students, higher performance had negative correlations with $\mathrm{LF}$ and positive ones with HF and rMSSD. Upon successful completion of the cognitive task, certain indicators interacted intensively with coherence in the delta range. Thus, between the LF, which characterizes the level of mental effort, and coherence in the above-mentioned EEG band, 6 negative correlations were recorded, and between the index of activity of the parasympathetic link of autonomic regulation (rMSSD) - 12 positive correlations. The most intense interaction there was between the HF spectrogram, which characterizes the activity of the vagus, namely 24 positive connections, which cover almost the entire cerebral cortex.

\section{Discussion}

Due to the fact that the relationship between the productivity of intuitive thinking and the peculiarities of cerebral cortex activation has almost not been studied, to describe and justify the results, we will refer to the existing studies of irrational human mental functions such as sensitivity intuition, defined by K. Jung's psychoanalytic model and the data on the study of different types of cognitive activity and creativity. The comparison of the electroencephalogram components characteristics revealed certain features in the spectral power of the alpha components of the EEG in the groups of female biology students with low and high productivity. In less successful individuals at the beginning of the mental task, a short- term increase in alpha rhythm in most areas of the cortex could be observed. We associated this reaction with the adjustment of cortical processes of excitation and inhibition to a certain type of mental activity and the choice of thinking strategy. Higher values of SP in the alpha range of the occipital areas of female students with low productivity in the testing of intuitive thinking indicate the participation of these systems of neural generators in the cortical analysis of visual patterns and the increase of attention concentration. In effective intuitive thinking, the differences in the spectral activity of the cerebral cortex are presented mainly in the posterior and temporal cortex in the alpha frequency range and are associated with irrational cognitive style of task performance. The decrease of alpha rhythm in the above areas can be considered a kind of characteristic of a certain functional state of the brain during a spontaneous intuitive thinking process. Razumnikova \& Ashanina (2017) point to the same features of desynchronization of alpha rhythm in persons with dominance of intuitive thinking over sensory when performing cognitive tasks of divergent type, linking these data with the correlates of decision strategies that arise on the basis of spontaneous responses as a result of memory resource use.

One of the functions of active synchronization in spontaneous EEG is the filtering of sensory information that enters the brain. This mechanism regulates perception, enhancing the processing of stimuli in one information flow and weakening it in the other one. In other words, it allocates brain resources by retaining the relevant channel to ensure both the effective reception of the desired stimulation and the response to it, which brings it closer to the functions of attention (Novikova, 2015). During stable visual attention, the synchronization of alpha activity reflects the work of active mechanisms of the cerebral cortex regulation system, which provide both local activation (reduction of alpha activity synchronization) of individual areas of the cortex and their local inactivation (increase in alpha amplitudes). It is assumed that all these mechanisms are based on the control system of local activation of the cerebral cortex (Guillery \& Harting, 2003). This brain system, which includes the frontal neocortex and its projections on the reticular nucleus of the thalamus, is able to control the activation or inactivation processes of individual neural ensembles of the cortex, which is reflected in local changes in spectral amplitudes of alpha rhythm (Suffczynski et al., 2001). It is noteworthy that the neurophysiological maturity of the cerebral cortex is evidenced by the coefficient of interhemispheric coherence of the alpha rhythm in the pair Fp1-Fp2, which has to be in the reference corridor 0.6-0.8 (Gazenkampf et al., 2015), which is quite characteristic of our subjects and indicates the neurophysiological maturity of the cerebral cortex and characterizes the ability to master the material successfully. Female students with low results of intuition tests in the pair Fp1-Fp2 had low values of coherence at the frequency of alpha rhythm, which corresponded to the minimum activity and interhemispheric integration in the above type of cognitive activity. However, in the subjects with high productivity, the synchronous operation of neural ensembles in the anterior zones of the right hemisphere and between the anterior zones of the right hemisphere and the frontal and temporal areas of the left one was noted. Synchronization of neural activity in the alpha range in the frontal and prefrontal areas in the subjects of both groups during mental activity is due to the fact that the tests required not only the consideration of the drawings, but also the involvement of internal representation, and the prefrontal cortex is an important structure for this type of cognitive function (Fuster, 2001). The effectiveness of performance of the intuition task is associated with the formation of functional connections in the prefrontal areas of both hemispheres. Our data, as well as the data from the other researchers (Lutzenberger et al., 1992) suggest that the complexity of changes in the frontal lobe of the brain at alpha frequency may indicate less orderly activation of the associative nodes in a creative approach to solving imaginative tasks and may reflect more vigorous competition between the cells, especially in situations where external stimulation is stopped or inhibited and is not taken into account. In general, the prefrontal cortex is a key structure through which cognitive activity is realized. It has extensive bidirectional cortico-cortical connections with the associative sites, and is also associated with limbic structures and has extensive connections to the projection areas. Our results are consistent with the data (Schupp et al., 1994), which indicate the role of the frontal lobe in the generation and retention of neural activity, that is 
based upon imagery, which is necessary for the formation of connections during cognitive activity. The presence of high functional connections in the alpha range in the posterior parts of the cortex is noteworthy, especially in the occipital-parietal areas in the individuals with high productivity of intuitive mental activity, which may be associated both with the increased occipital blood flow during viewing of the visual image and with creativity. Similar results were obtained by other researchers (Jausovec, 2000), who showed that creative problems are solved with greater bilateral power and coherence of alpha rhythm in the frontal and parieto-occipital regions. Pronounced short interhemispheric connections indicate the possibility of solving the problem with the help of rapid analysis through the corpus callosum that contributes to the speed, ease and productivity of cognitive tests, and, according to Karpova \& Dikaya (2014) such functional connections are formed as a result of professional training.

In intuitive thinking, the coherence of cortical structures in the beta1subband of the EEG in the students with low productivity was observed between the long interhemispheric between symmetrical leads, and in the students with high productivity - in the interhemispheric anterior cortex respectively. The work of neurons in the central-parietal-temporal loci of the right and left hemispheres and in the interhemispheric central-parietaltemporal ones was synchronized in the students of both groups. Thus, desynchronization is associated not only with a decrease in alpha rhythm, but also with an increase in beta activity. With successful cognitive activity at the beginning of the acquaintance with the task, there was a sharp increase in the relative power of the entire beta range, which indicates the rapid activation of brain mechanisms and the activating of areas responsible for productive thinking. The obtained data are consistent with the facts about the pronounced high-frequency beta1-rhythmic component, which may indicate a rapid functional organization of brain structures with the inclusion of automated components of mental processes in successful individuals.

In intuitive thinking, the absolute $\mathrm{SP}$ of betal components in the students with low productivity was within the background values, except for the T6 zone, and the students with high productivity had lower values in the central, parietal and occipital loci of both hemispheres of the brain. Some researchers point to an increase in the power of betal-band waves under mental workload (Allahverdiev et al., 2018). But there are data that show that mental workload is associated with a decrease in the power of the betal component of the EEG, for example, such changes are associated with the increased levels of brain activation (Bogomolov et al., 2015). The possibility of participation of betal-rhythm in the processing of high-order information, during which it is necessary to compare new and old information, or to integrate information coming from different modalities was pointed out by (Kopel et al., 2010). Unfortunately, there is little information about this, and the data on the neurophysiological mechanisms of intuitive thinking are missing.

Although in the literature available to us we have not found any data on the synchronization of EEG at betal frequency in intuitive thinking and this requires further in-depth study, we can assume that intuition is accompanied by optimization of the interaction of cortical neurons in the betal range, which leads to higher performance of this cognitive activity. Regarding the functional significance of the beta rhythm, there is no single point of view. It is considered as an indicator of brain activation due to various effects on reticular formation. As a rule, with increasing levels of brain activation in the EEG there is an increase in the power of beta frequencies. This is shown in the development of an indicative reaction, in terms of solving problems of various complexity, when reading texts, etc. However, sometimes researchers report that in similar conditions, the power of beta frequencies may not only not increase, but even decrease. This is shown, in particular, in the precentral areas when performing movements and in the parietal areas when reading texts. A number of researchers note a decrease in beta-rhythm in the frontal areas after prolonged cognitive load (Jap et al., 2009), but some scientists, on the contrary, note an increase in beta-rhythm in the frontal leads F3, F4 during long-term cognitive tasks (Boksem et al., 2006).

In intuitive thinking of the female students with low productivity, the EEG synchronizations in the betal-range in the anterior zone of the right and posterior parts of the left hemisphere, in the central-parietal-temporal leads of the left hemisphere and interhemispheric ones, were recorded.
In the students with high productivity of this type of thinking, the number of probable coherent connections in the above EEG band increased, there were probable intrahemispheric long coherences between the anterior and posterior parts of the right hemisphere and interhemispheric synchronizations in the anterior cortex, but the coherences disappeared in the centralparietal-temporal areas, which is a sign of more formed and coordinated one. They also have short interhemispheric connections between the symmetrical leads of both hemispheres, which may indicate a rapid and familiar analysis of information to each person in the task. Desynchronization in mental activity was expressed in the growth of high-frequency beta2index of the EEG, which was more pronounced in the students with high productivity with the intuitive type of thinking. In addition, the individuals with high productivity in this range had a higher average spectral power and the asymmetry with dominance in the right hemisphere was marked.

The SP of beta 2 components probably increased in the anterior cortex in the female students of both groups, which is associated with the participation of the latter in the regulation of active functional level and attention, in the analysis of visual information and processes of "nonverbal categorization" and the response to new stimuli. In intuitive thinking, the occipital point $\mathrm{T} 5$ of the left and central hemispheres of the right hemisphere was activated in the students with low productivity, and the whole cerebral cortex was activated in the high-productive ones. The increase in the power of the waves of the above range was also found by Razumnikova (2017) in women - "intuitionists" with divergent thinking.

In general, a comparison of the features of the organization of cortical areas in people with different productivity of cognitive activity shows that this activity is achieved due to different options for activation of the cortex. In intuitive thinking, the effective performance of the task corresponds to larger values of the spectral power of beta2 and less SP alpha activity, while in people with low productivity of the task performance there was a less significant decrease in SP alpha and a tendency to increase beta2 activity. In intuitive thinking, the changes in the beta- 2 range were less significant.

In intuitive thinking, the central-parietal-temporal zones of the right and left hemispheres and interhemispheric central-parietal-temporal locations worked synchronously in low-productive biology female students, while in high-productive students the central-parietal-temporal locations remained in the left hemisphere and the interhemispheric central-parietaltemporal coherences appeared. In intuitive thinking, the value of the SP index in the delta range increases significantly. Our data are consistent with the data (Fernández et al., 1995) which also found an increase in delta activity when performing different types of mental tasks. If we talk about the specific "foci" of delta oscillations, in the students with low productivity of intuitive tasks a slight but probable $(\mathrm{P}<0.05)$ increase in $\mathrm{P} 4$ and in the occipital loci of the cerebral cortex was noted, while in people with high productivity - in Fp1, F7, O1, T3 assignments of the left hemisphere and the majority of assignments of the right one. Thus, the increase in the productivity of intuitive thinking is accompanied by a probable increase in the delta components of the EEG in the anterior parts of the cortex. Vajz (1998) notes that the emergence of an intuitive response is associated with hyperactivation of delta waves on the EEG together with higher frequencies, and, in her opinion, it is the brain response that distinguishes intuitive thinking from the other types of cognitive activity (Geraimchuk, 2012). According to the concept of Vajz (1998), "enlightenment" and "inspiration" in cognitive activity are associated with hyperactivation of delta waves on the EEG together with higher frequencies of the brain. This, in her opinion, distinguishes the above conditions from the usual ones (Geraimchuk, 2012). In our opinion, such synchronization of delta activity of the EEG, on the one hand, may reflect the activation of inhibitory processes on external stimuli tasks, and,on the other hand, it may be associated with a special state of the cerebral cortex during intuitive thinking, which reflects the degree of "tuning" to the activities related to the processes of information selection and awareness.

Also, to explain the obvious contradiction between the increase in delta waves during performance of mental tasks and the fact that this activity is the main characteristic of slow sleep, V. Vogel and co-authors postulated the existence of two types of "behavioral inhibition", which are represented by slow waves in the EEG. They attributed "Class I inhibition" to the gross inactivation of the entire process of arousal as a result of relaxation, 
as in a dream. "Class II inhibition" selectively suppresses inappropriate or insignificant neural activity during the performance of a mental task. During slow sleep, a progressive change in the EEG (increased delta activity) occurs by reducing the activation of thalamo-cortical cells by reducing the activity of cholinergic and monoaminergic neurons of the posterior hypothalamus and basal ganglia of the forebrain, and by reducing glutamatergic activation of climatergic corticosteroids. The results observed during performance of mental tasks cannot be explained by such progressive deactivation. Thus, a mechanism initiated by a mental task may exist, but it is currently unknown. One possibility is that when performing cognitive tasks that require attention during internal information processing, the corticofugal pathway suppresses the thalamocortical cells, and thus activates the functional disconnection of the cortex from stimuli for selective processing of internal information. This will be "class II inhibition", which is characterized by the presence of slow activity in the EEG. In their study Fernández et al. (1995) described similar changes in solving arithmetic problems and associated them with an increase in the internal concentration of subjects when performing tasks, with the complexity of tasks and emotional factors (Inouye et al., 1993). Increased delta activity has been reported in the studies (Fernández et al., 1995) when performing different types of mental tasks.

In the range of delta waves of the EEG, as in the other ranges, in most of the studies involving mental loads short and long interhemispheric synchronization between symmetrical leads were observed. The greatest integration of cortical zones in the delta range was observed: in the lowproductive individuals - in the central-parietal-temporal zones of the right and left hemispheres and between the two hemispheres; in the high-productive ones - in the anterior parts of both hemispheres and in the posterior part of the right hemisphere, between the anterior and posterior parts of the right hemisphere, interhemispheric in the anterior parts of the cortex, interhemispheric diagonal between the anterior parts of the left hemisphere and posterior parts of the right, central-parietal-temporal ones.

An increase in the theta-rhythm index may, on the one hand, indicate some pathology, and on the other hand, it can reflect certain functional states associated with either a decrease in brain activity, or, conversely, with attention concentration, cognitive and emotional activation (Zvyozdochkina, 2014). This is the activation reaction we observed under cognitive workload, and the largest values of relative spectral power in this range were recorded in high-productive female students in intuitive thinking. Zone-averaged spectral power in this low-frequency high-amplitude range probably increased in female students of both groups, especially in highproductive ones.

When performing the task on intuition, the power of theta components of the EEG in the polar, occipital and some temporal leads of both hemispheres increased in low-productive individuals. The increase in task performance was associated with an increase in SP in the theta range, especially in the anterior areas of the cortex (by the way, like in the previous delta range). We have to note that the theta system, on the one hand, is associated with the implementation of behaviour that determines the relationship between internal enlightenment processes and life experiences (Knyazev, 2011), and, on the other hand, it is involved in emotional information processing (Aftanas, 2000). Given the nature of the tasks being performed, we tend to believe that the increase in SP in the theta range is a reflection of the response that is formed as a "trust of experience", or the first solution. We also add that the theta system is also associated with the delta system, but, unlike the latter, implements the behaviour more flexibly, "comparing" the internal drivers of delta systems with the accumulated life experience (Knyazev, 2011).

The students of two groups with an intuitive type of thinking were characterized by intrahemispheric short synchronization in the posterior parts of both hemispheres. In low-productive students there were high coherences in the anterior parts of the left hemisphere and interhemispheric central-parietal-temporal ones, and high-productive students demonstrated interhemispheric central-parietal-temporal-occipital, interhemispheric diagonal ones between the anterior parts of the left hemisphere and the posterior parts of the right and multiple ones between the frontal leads and the other points of both hemispheres. The increase of long coherent bonds in the theta band suggests that when performing cognitive tasks there is an inverse control between the supposed images and the real illustrations or the text, and the concentration of attention increases. The subjects constantly referred to the image, checking the created images, or the formed answers, and this was especially characteristic of less successful persons. We believe that the above changes also reflect the emotional component (Shemyakina \& Dan'ko, 2004), which is associated with the satisfaction of highly successful students when testing for intuitive thinking, and the presence of short interhemispheric intersymmetric connections indicates the usual mental strategies used by the subjects in task performance.

If intuition is based on neurological processes of perception and learning, then we must be able to improve decisions based on "intuition". Wan et al. (2012) demonstrated this during the training of beginners in the game Shogi (Japanese chess). The researchers believe that the knowledge of the "next move" in the game indicates the knowledge that we usually call "intuitive knowledge". In the process of training, these cycles are organized to gain knowledge and experience, and the processes of creating the best next move (at least in the game Shogi) become fast and automatic, namely, intuitive (Wan et al., 2012). The other studies show that intuitive generation of subsequent moves in board games is based on the rapid perception of patterns (Gobet, 2001). Activation of the parietal region of the cerebral cortex by retrieving information from episodic memory was shown in the studies (Cabeza et al., 2008). The researchers (Wan et al., 2012) found that there is a strong correlation between the head of the caudate nucleus and the prefrontal and premotor areas of the cortex during the rapid generation of the best next step in the game. The scientists suggested that in professional players this part of the basal ganglia effectively coordinates prefrontal and premotor schemes to achieve a specific goal.

The increased synchronization of EEG components in the prefrontal areas and in the loci of the motor cortex found in our studies, suggests that such neurophysiological mechanisms may underlie the intuitive thinking, and the performance of tests is associated with more experience and better knowledge of the material. Thus, the topographic signs of synchronization of electrical processes of the cerebral cortex, which are detected during their mapping, can serve as objective criteria for the success of intuitive thinking, which allow prediction of both individual abilities and the state that contributes to its implementation. This opens up the prospects for controlling the intuitive component of cognitive activity in the process of vocational training. Neurophysiology shows us that intuition is a scientific set of skills and knowledge, so we must learn intuition, which leads to better and faster decision-making. Knowledge of intuition becomes both an individual and public good.

The cardiovascular system (CVS) is one of the most important life support systems of the body. The reaction of CVS, its neurohumoral regulation, to internal and external influences depends on the activity and interaction of parasympathetic and sympathetic elements of ANS. The nature of the changes that are determined by observations at rest and in response to physical or mental stress can be judged on the functional state of the CVS and the body as a whole. It participates in all adaptive reactions of the whole organism, reacting to even minor influences, while maintaining homeostasis.

Comparative analysis of the results of vegetative support of mental activity indicates the peculiarities of the mechanisms of regulation in people with different productivity of intuitive thinking. In low-productive female biology students, the response of the CVS to intuitive thinking was expressed in an increase in heart rate, a decrease in the coefficient of variation (CV) and a reduction in the R-R interval, and the latter reflects the end result of numerous regulatory effects on sinus rhythm. There is a decrease in modal value (Mo) and increase in mode amplitude, voltage index of regulatory systems, increase in autonomic balance index (IER), the latter indicator is a sign of humoral channel activation with increasing advantage of adrenergic regulatory mechanisms. Decreases in rMSSD, pNN50, SDNN indicate a shift in the autonomic balance towards the sympathetic division. The increase in ARP also reflects the advantage of the sympathetic ANS in the regulation of the sinus node under cognitive load.

The spectral method of analysis is the most adequate for the assessment of parasympathetic and sympathetic activity in a short period of time. Spectral parameters are consistent with the above conclusions and reflect the contribution of cerebral ergotropic zones in the regulation of cardiac arrhythmia during mental activity. Intuitive thinking revealed a 
moderate decrease in the absolute values of TP, the predominance of LFwaves over VLF and HF, a decrease in HF-waves, an increase in the relative amount of $\mathrm{LF} \%$ and a decrease in $\mathrm{HF} \%$. The index of centralization (IC) is within the norm, which indicates that in this case there is a balance between the activity of segmental and suprasegmental circuits of vegetative management.

Thus, the performance of tests for intuitive thinking by low-productive students is accompanied by a moderate predominance of sympathetic and central regulation of heart rate and a decrease in the activity of the autonomic control circuit. We attributed this type of heart rate regulation to a high level of central heart rate regulation. At high productivity of intuitive thinking, the changes of HRV indicators indicate the advantage of a parasympathetic link of regulation. In general, in female biology students with high-productivity in intuitive thinking we noted the optimal state of the body's regulatory systems, which reflects the adequate energy-saving level of response to stress and demonstrates the body's fitness and constant use of these cognitive activities in the learning process (Shlyk \& Zufarova, 2013). High contribution of the parasympathetic division to the regulation of cardiac activity in students was noted in the other works (Cherbakov, 2011; Govoruhina et al., 2017). Thus, summarizing the results of changes in the parameters of CIG, we can say that in the students with a predominance of intuitive thinking, the usual mental load is accompanied by the activation of the parasympathetic division of the ANS.

Analyzing the features of the interaction of lability of spectral-coherent characteristics of EEG potentials and heart rate variability, it was found that the successful performance of intuition tests was facilitated by the formation of positive relationships between the coherence in the delta range and the power of high-frequency HF component of the heart rhythm wave structure and between the indicator of activity of a parasympathetic link of autonomic regulation (rMSSD). Also, the coherence of bioelectrical activity in the delta wave range was negatively correlated with LF. Thus, the task performance with the involvement of intuition was accompanied by a coordinated synchrony of the EEG in the delta range and the increase of parasympathetic regulation mechanisms of the cardiovascular system. There is a special role of delta rhythm in situations involving the prediction of events and the effectiveness of responding to the proposed stimuli (Stefanics et al., 2010). The authors suggest that lowfrequency activity plays a functional role in prediction mechanisms by modulating synchronized fluctuations in the activity of large populations of neurons and by facilitating contacts between the areas of the brain responsible for sensory processing and response realization. In addition, delta activity of the frontal cortex modulates the occipital alpha rhythm, thereby facilitating selective visual perception (Helfrich et al., 2017). Effective work also depends on a calm, focused state, which is achieved through vegetative effects on HRV and activation of the parasympathetic link of regulation and is a characteristic of people who use intuition in everyday life.

Summarizing the results of the last series of studies, we can conclude that productive mental activity of the intuitive type is due to the specific integration of cortico-visceral processes, namely, that productive intuitive thinking is associated with activation of autonomic regulation of HRV and the coherence in evolutionarily older delta and delta-theta brain systems.

\section{Conclusion}

The lability of physiological functions, manifested at the peripheral and central levels, facilitates the productivity of the intuitive type of thinking. High productivity of mental type of cognitive activity is provided by speed and accuracy of the tests' performance.

The productivity of intuitive thinking is associated with increasing the spectral power of beta2-, delta-, theta-components of the EEG. The synchronization of the activity of most frequency bands is manifested in the frontal and motor areas of the cortex, which have close connections with the basal ganglia, responsible for the formation of skills. In the betal-band there are probable intrahemispheric long coherences between the anterior and posterior parts of the right hemisphere, and large cellular ensembles are combined at beta1, 2 frequency and theta-bands of EEG, which cover the central-parietal-temporal loci of the cortex. Synchronization of biopotentials in the delta-band covers large areas of the cerebral cortex.
Comparative analysis of the results of vegetative support of mental activity indicates the peculiarities of the mechanisms of regulation in people with different productivity of intuitive thinking:

- in individuals with low productivity, cognitive activity is associated with a predominance of central and sympathetic influences in the management of the cardiovascular system.

- in individuals with high productivity, intuitive thinking is accompanied by a moderate predominance of autonomic regulation of $\mathrm{HRV}$, which reflects the optimal state of the body's regulatory systems and is a sign of lower energy consumption of the body's regulatory systems to maintain homeostasis while increasing the effectiveness of this type of cognitive activity and connected with the state of training of the female students and the constant use of this type of thinking in the learning process.

Correlation analysis found that productive and mental activity is caused by the specific integration of cortico-visceral processes: productive intuitive thinking is associated with the activation of autonomic regulation of HRV and coherence in the evolutionarily older delta and delta-theta systems of the brain.

The obtained results make it possible to predict the individual success of intellectual activity. They can be a scientific basis for the development of training programs for specialists in the field of natural sciences, for the development of individual curricula, as well as monitoring the effectiveness of their use in the process of adaptation of students to educational activities and be taken into account in cognitive psychocorrection.

\section{References}

Aftanas, L. I. (2000). Emocional'noe prostranstvo cheloveka: Psihofiziologicheskij analiz [Human emotional space ; psychophysiological analysis]. Sibirskoye Otdyeleniye Rossiiskoi Akademii Medicinskih Nauk, Novosibirsk (in Russian).

Allahverdiev, A. R., Allahverdieva, A. A., \& Babaev, E. C. (2018). Osobennosti bioelektricheskoj aktivnosti golovnogo mozga zhenshchin 50-60 let pri umstvennoj deyatelnosti $\mathrm{v}$ dni slabyh geomagnitnyh vozmushchenij i v otnositelno spokojnyie dni [Features of the bioelectrical activity of the brain of 50-60 year old women with mental activity on days of weak geomagnetic disturbances and on relatively calm days]. Scientific Review, Biological Sciences, 4, 5-11 (in Russian).

Baievskij, R. M., Ivanov, G. G., \& Chirejkin, L. V. (2001). Analiz variabel'nosti serdechnogo ritma pri ispol'zovanii razlichnyh elektrograficheskikh sistem [Analysis of heart rate variability using various electrographic systems]. Joumal of Arrhythmology, 24, 65-87 (in Russian).

Bekhtereva, N. P., Gogolicyn, Y. L., Kropotov, Y. D., \& Medvedev, S. V. (1985). Nejrofiziologicheskie mekhanizmy myshleniya [Neurophysiological mechanisms of thinking]. Nauka, Leningrad (in Russian).

Bogomolov, A. M., Bulatova, O. V., Traskovsky, V. V., Bushov, Y. V., \& Litvinova, N. A. (2015). Polovyie osobennosti korkovykh vzaimodejstvij v svyazi s tochnost'yu uznavaniya korotkikh intervalov vremeni i individual'no-psikhologicheskimi svojstvami [Sex differences of cortical interactions in connection with the accuracy of short time intervals recognition and individual psychological characteristics]. Bulletin of Kemerovo State University, 62, 7-16 (in Russian).

Boksem, M. A. S., Meijman, T. F., \& Lorist, M. M. (2006). Mental fatigue, motivation and action monitoring. Biological Psychology, 72(2), 123-132.

Bondarenko, M. P., Bondarenko, O. V., Kravchenko, V. I., \& Makarchuk, N. Y. (2016). EEG activity in dextrals and sinistrals during visual monocular/binocular perception of verbal emotionally colored information. Neurophysiology, 48, 43-53.

Cabeza, R., Ciaramelli, E., Olson, I. R., \& Moscovitch, M. (2008). The parietal cortex and episodic memory: An attentional account. Nature Reviewes Neuroscience, $9,8,613-625$.

Craik, A., He, Y., \& Contreras-Vidal, J. L. (2019). Deep learning for electroencephalogram (EEG) classification tasks: A review. Journal of Neural Engineering,16(3), 1-29.

Fernández, T., Harmony, T., Rodriguez, M., Bernal, J., Silva, J., Reyes, A., \& Marosi, E. (1995). EEG activation patterns during the performance of tasks in volving different components of mental calculation. Electroencephalography and Clinical Neurophysiology, 94(3), 175-182.

Fink, A., Rominger, C., Benedek, M., Perchtold, C. M., Papousek, I., Weiss, E. M., Seidel, A., \& Memmert, D. (2018). EEG alpha activity during imagining createve moves in soccer decision-making situations. Neuropsychologia, 114, 118-124.

Fuster, J. M. (2001). The prefrontal cortex - an update: Time is of the essence. Neuron, 30, 319-333.

Gazenkampf, K. A., Dmitrenko, D. V., Shnajder, N. A., Medvedeva, N. N., Nikolaev, V. G., Romanenko, A. A., Solomatova, E. S., \& Yakovleva, K. D. (2015). Kharakteristika al'fa ritma i koefficienta mezhpolushamoj kogerentnosti kak 
markerov mezhpolushamoj integracii u lyudej yunosheskogo vozrasta [Characteristics of the alpha rhythm and the coefficient of interhemispheric coherence as markers of interhemispheric integration in adolescents]. Modern Problems of Science and Education, 4, 1-6 (in Russian).

Geraimchuk, I. M. (2012). Teoriya tvorcheskogo processa: Struktura razuma (intellekta) [Creative process theory: The structure of the mind (intellect)]. Edelveis, Kiev (in Russian).

Gobet, F., Lane, P. C., Croker, S., Cheng, P. C., Jones, G., Oliver, I., \& Pine, J. M. (2001). Chunking mechanisms in human learning. Trends in Cognitive Sciences, 5(6), 236-243.

Govorukhina, A. A, Mal'kov, O. A., Nifontova, O. L., \& Novoselova, A. A. (2017) Sostoyanie regulyatomykh mekhanizmov i sosudistogo rusla organizma studentov fakul'teta fizicheskoj kul'tury i sporta, prozhivayushchikh v KhMAOYugre [The state of the regulatory mechanisms and the vascular bed of the organism of students of the Faculty of Physical Culture and Sports, living in KhMAO-Yugra]. Teorija i Praktika Fizicheskoj Kul'tury, 8, 25-27 (in Russian).

Guillery, R. W., \& Harting, J. K. (2003). Structure and connections of the thalamic reticular nucleus: Advancing views over half a century. The Journal of Comparative Neurology, 463(4), 360-371.

Gusel'nikov, V. I. (1976). Elektrofiziologiya golovnogo mozga [Electrophysiology of the brain]. Vysshaya Shkola, Moscow (in Russian).

Helfrich, R. F., Huang, M., Wilson, G., \& Knight, R. T. (2017). Prefrontal cortex modulates posterior alpha oscillations during top-down guided visual perception. Proceedings of the National Academy of Sciences, 114(35), 9457-9462.

Inouye, T., Shinosaki, K., Iyama, A., \& Matsumoto, Y. (1993). Localization of activated areas and directional EEG patterns during mental arithmetic. Electroencephalography and Clinical Neurophysiology, 86(4), 224-230.

Jap, B. T., Lal, S., Fischer, P., \& Bekiaris, E. (2009). Using EEG spectral components to assess algorithms for detecting fatigue. Expert Systems with Applications, $36(2), 2352-2359$.

Jausovec, N. (2000). Differences in cognitive processes between gifted, intelligent, creative, and average individuals while solving complex problems: An EEG study. Intelligence, 28(3), 213-237.

Karpova, V. V., \& Dikaya, L. A. (2014). Osobennosti funkcional'nykh svyazej kory mozga u ispytuemykh s raznym urovnem produktivnosti obraznoj tvorcheskoj deyatel'nosti [Features of functional connections of the cerebral cortex in subjects with different levels of productivity of imaginative creative activity]. North Caucasian Psychological Bulletin, 12(2), 42-46 (in Russian).

Knyazev, G. G. (2011). Cross-frequency coupling of brain oscillations: An impact of state anxiety. International Journal of Psychophysiology, 80, 236-245.

Konogorskaya, S. A. (2017). Osobennosti prostranstvennogo myshleniya i ikh vzaimosvyaz' s uchebnoj uspeshnost'yu obuchayushchikhsya [Features of spatial thinking and their relationship with the educational success of students]. Scientific and pedagogical review. Pedagogical Review, 15, 142-152 (in Russian).

Kopell, N., Kramer, M. A., Malerba, P., \& Whittington, M. A. (2010). Are different rhythms good for different functions? Frontiers in Human Neuroscience, 4, 1-8.

Kupa, L. V., \& Filimonova, N. B. (2014). Zminy aktyvnosti holovnoho mozku cholovikiv pry vykonanni verbalnykh subtestiv lohichnoho vidboru ta vyznachennya zahalnykh rys testu Amthauera [Changes in the activity of the brain of men when performing verbal subtests of logical selection and determining the general features of the Amthauer test]. Bulletin of Cherkasy University, Biological sciences, 2, 64-69 (in Ukrainian).

Kutsenko, T. V., Husak, I. I., \& Petrushenko, M. O. (2013). Verbalna i neverbalna kreatyvnist, variatyvnist sertsevoho rytmu ta pokazniki vlastivostei psyhofizyolohichnykh funktsii u zhinok i cholovikiv [Verbal and nonverbal creativity, heart rate variability and indicators of the properties of psychophysiological functions in women and men]. Bulletin of Cherkasy University, Biological Sciences, 2, 52-57 (in Ukrainian).

Livanov, M. N., Korol'kova, T. A., \& Sviderskaya, N. E. (1988). Prostranstvennaya sinhronizaciya bioelektricheskoj aktivnosti kory golovnogo mozga kak pokazatel' intellektual'noj rabotosposobnosti cheloveka [Spatial synchronization of the bioelectrical activity of the cerebral cortex as an indicator of human intellectual performance]. In: Livanov, M. N., Rusinov, V. S., \& Simonov, P. V. (Eds.). Diagnostika i prognozirovanie funkcional'nogo sostoyaniya mozga cheloveka [Diagnostics and prediction of the functional state of the human brain]. Nauka, Moscow. Pp. 7-51 (in Russian).

Lutzenberger, W., Elbert, T., Birbaumer, N., Ray W. J., \& Schupp, H. (1992). The scalp distribution of the fractal dimension of the EEG and its variation with mental tasks. Brain Topography, 5(1), 27-34.

Lyzohub, V. S., Yukhymenko, L. I., Khomenko, S. M., \& Kozhemyako, T. V. (2014). Neirofizyolohichne ta vehetatyvne zabezpechennya pererobky sluhovoii informatsii v osib z riznym rivnem funktsionalnoii rukhlyvosti nervovykh protsesiv [Neurophysiological and autonomic support of auditory information processing in persons with different levels of functional mobility of nervous processes]. Science and Education, 8, 110-114 (in Ukrainian).

Makarchuk, M. Y., Maksymovych, K. Y., Kravchenko, V. I., \& Kryzhanovskyi, S. A. (2010). EEH-aktyvnist u zhinok pry spryiniatti emotsiino zabarvlenykh, erotychnykh ta neitralnykh zobrazhen $v$ riznykh fazakh ovuliatsiinoho (men- strualnoho) tsyklu [EEG activity in women in the perception of emotionally coloured, erotic and neutral images in different phases of the ovulatory (menstrual) cycle]. Neurophysiology, 42(5), 433-441 (in Ukrainian).

Novikova, S. I. (2015). Ritmy EEH i kognitivnyie processy [EEG rhythms and cognitive processes]. Contemporary Foreign Psychology, 4(1), 91-108 (in Russian).

Okhrei, A. G., Kutsenko, T. V., \& Makarchuk, M. Y. (2016). Vykonannya testu Strupa z vyznachennyam prostorovoii lokalizatsii stymuliv muzykantamy ta ne muzykantamy [Performing a Stroop test to determine the spatial localization of stimuli by musicians and non-musicians]. Bulletin of Cherkasy University, 82 89 (in Ukrainian)

Poruchynska, T., Shevchuk, T., Romanyuk, A., \& Dmytrotsa, O. (2016). Osoblyvosti teta-aktyvnosti EEH mozku osib z riznoyu syloyu nervovykh protsesiv pid chas verbalnoii ta neverbalnoii diyalnosti [Features of theta activity of EEG of the brains of persons with different strength of nervous processes during verbal and nonverbal activity]. Biological Systems, 8(1), 138-142 (in Ukrainian).

Razumnikova, O. M., \& Yashanina, A. A. (2017). Znacheniie racional'nogo ili irracional'nogo kognitivnogo stilya $\mathrm{v}$ reaktivnosti al'fa-ritma pri konvergentnom i divergentnom myshlenii [Significance of rational or irrational cognitive style in alpha-rhythm reactivity in convergent and divergent thinking]. Russian Physiological Joumal named after I. M. Sechenov, 3, 348-358 (in Russian).

Riganello, F., Candelieri, A., Quintieri, M., Conforti, D., \& Dolce, G. (2010). Heart rate variability: An index of brain processing in vegetative state? An artificial intelligence, data mining study. Clinical Neurophysiology, 121(12), 2024-2034.

Samokhin, I. S., Sokolova, N. L., \& Sergeeva, N. G. (2016). Rezul'tativnost' i komfortnost' obucheniya kak osnovnye kriterii ego uspeshnosti [The effectiveness and comfort of training as the main criteria for its success]. Scientific Dialogue, 5(53), 234-253 (in Russian).

Sastre-Riba, S., \& Ortiz, T. (2018). Executive neurofunctionality: A comparative study in high intellectual abilities. Revista de Neurologia, 66(S1), 51-56.

Schupp, H. T., Lutzenberger, W., Birbaumer, N., Miltner, W., \& Braun, C. (1994). Neurophysiological differences between perception and imagery. Cognitive Brain Research, 2(2), 77-86.

Shcherbakov, N. S. (2011). Analiz variabel'nosti serdechnogo ritma pri funkcional'noj nagruzke i v sostoyanii pokoya [Analysis of heart rate variability during functional load and at rest]. Health and Education in the XXI Century, 13, 4 (in Russian).

Shemyakina, N. V., \& Dan'ko, S. G. (2004). Vliyaniie emocional'noj okraski vosprinimaemogo signala na elektroencefalograficheskiie korrelyaty tvorcheskoj deyatel'nosti [Influence of the emotional coloring of the perceived signal on the electroencephalographic correlates of creative activity]. Human Physiology, 30(2), 22-29 (in Russian).

Shlyk, N. I., \& Zufarova, E. I. (2013). Normativy pokazatelej variabel'nosti serdechnogo ritma u issleduiemykh 16-21 goda s raznymi preobladayushchimi tipami vegetativnoj regulyacii [Standards for heart rate variability in subjects aged 16 21 with different prevailing types of autonomic regulation]. Bulletin of the Udmurt State University, 4, 96-105 (in Russian).

Snezhkova, N. N. Maksimenko, M. Y., \& Larinova, L. G. (2011). Verbal'no-logicheskoe i naglyadno-obraznoe myshlenie $\mathrm{v}$ raznykh eksperimental'nykh usloviyakh $\mathrm{u}$ detej s raznym tipom ontogeneza [Verbal-logical and visual-figurative thinking in different experimental conditions in children with different types of ontogenesis]. Bulletin of State University of Management, 16, 103-106 (in Russian).

Stefanics, G., Hangya, B., Hernádi, I., Winkler, I., Lakatos, P., \& Ulbert, I. (2010). Phase entrainment of human delta oscillations can mediate the effects of expectation on reaction speed. The Joumal of Neuroscience, 30(41), 13578-13585.

Suffczynski, P., Kalitzin, S., Pfurtscheller, G., \& Lopes da Silva, F. H. (2001). Computational model of thalamo-cortical networks: Dynamical control of alpha rhythms in relation to focal attention. International Journal Psychophysiology, 43(1), 25-40.

Talukdar, U., Hazarika, S. M., \& Gan, J. Q. (2019). Motor imagery and mental fatigue: Inter-relationship and EEG based estimation. Joumal of Computational Neuroscience, 46(1), 55-76.

Tikhomirova, T. N., Modyaev, A. D., Leonova, N. M., \& Malykh, S. B. (2015). Faktory uspeshnosti v obuchenii na nachal'noj stupeni obshchego obrazovaniya: Polovyie razlichiia [Factors of success in learning at the initial stage of general education: Gender differences]. Psychological Journal, 36(5), 43-54 (in Russian).

Vajz, A. (1998). Vdokhnovenie po zakazu [Inspiration on demand]. Popurri, Minsk (in Russian).

Voss, J. L., \& Paller, K. A. (2009). An electrophysiological signature of unconscious recognition memory. Nature Neuroscience, 12, 349-355.

Wan, X., Takano, D., Asamizuya, T., Suzuki, C., Ueno, K., Cheng, K., Ito, T., \& Tanaka, K. (2012). Developing Intuition: Neural correlates of cognitive-skill learning in caudate nucleus. Journal of Neuroscience, 32(48), 17492-17501.

Yin, Z., \& Zhang, J. (2017). Cross-session classification of mental workload levels using EEG and an adaptive deep learning model. Biomedical Signal Processing and Control, 33, 30-47.

Zvyozdochkina, N. V. (2014). Issledovaniie elektricheskoj aktivnosti golovnogo mozga [Study of the electrical activity of the brain]. Kazan University, Kazan (in Russian). 